\title{
A new glass tetra species of Phenacogaster from the rio Salitre, rio São Francisco drainage, Brazil (Characiformes: Characidae)
}

\author{
Zilda Margarete Seixas de Lucena and Carlos Alberto Santos de Lucena
}

A new species of Phenacogaster is described from the rio Salitre, a tributary of the lower middle rio São Francisco drainage. The new species can be clearly distinguished from all its congeners in having a conspicuous, broad caudal peduncle spot reaching the upper and lower margins of the peduncle with a short extension onto the middle caudal fin rays and another weaker extension over the lower lobe of the caudal fin.

Keywords: Bahia State, Caatinga, Neotropical fish, Taxonomy.

Uma nova espécie de Phenacogaster é descrita do rio Salitre, afluente da drenagem do submédio rio São Francisco. A nova espécie é facilmente distinguida de todas as congêneres por apresentar uma conspícua e larga mancha no pedúnculo caudal que alcança as margens superior e inferior do pedúnculo com uma curta extensão sobre os raios medianos e outra mais fraca sobre o lobo inferior da nadadeira caudal.

Palavras chave: Caatinga, Estado da Bahia, Peixes neotropicais, Taxonomia.

\section{Introduction}

The monophyletic genus Phenacogaster Eigenmann currently comprises 22 species distributed throughout the river basins of Amazon, Orinoco, Tocantins, Paraguay, and São Francisco; the coastal rivers of northern and northeastern Brazil and the Guianas (Lucena, Malabarba, 2010; Antonetti et al., 2018); and the middle rio Paraná basin (Casciotta et al., 2003).

To date, the only species of the genus mentioned from the rio São Francisco drainage is Phenacogaster franciscoensis, which was described by Eigenmann (1911) based on specimens obtained from "Boqueiras, near mouth of Rio Porto (=Preto)" (Lucena, Malabarba, 2010). In this paper, we describe the second species of the genus from that drainage based on samples collected 21 years ago from the rio Salitre basin.

\section{Material and Methods}

Examined specimens belong to the Museu de Ciências e Tecnologia, Pontifícia Universidade Católica do Rio Grande do Sul, Porto Alegre (MCP), Museu Nacional, Rio de Janeiro (MNRJ), and Museu de Zoologia da Universidade de São Paulo, São Paulo (MZUSP). Morphometric and meristic data are described following the methods described by Fink,
Weitzman (1974) and Malabarba, Lucena (1995). The measurements were taken using a digital caliper on the left side of each specimen always straight-line projections between two points. Counts of vertebrae, dentary teeth, and supraneurals were taken from cleared and stained specimens (c\&s) prepared using the protocol specified by Taylor, van Dyke (1985). Vertebrae of the Weberian apparatus were counted as four elements and the fused PU1+U1 considered a single element. All measurements are expressed as percentages of standard length (SL), except subunits of the head, which are expressed as percentages of head length. In the Description the frequency of each count is provided in parentheses and the count of the holotype is indicated by an asterisk. In the Results section, the catalog number of the paratypes is followed by the total number of specimens in the lot, the range of standard lengths the number of specimens that were counted and measured, and the respective range of standard lengths (in parentheses).

\section{Results}

\section{Phenacogaster julliae, new species}

urn:1sid:zoobank.org:act:38E707F 8-40C 8-4258-8608F276CB230154

Figs. 1-3, Tab. 1

PUCRS, Museu de Ciências e Tecnologia, Pontifícia Universidade Católica do Rio Grande do Sul, Av. Ipiranga, 6681, P.O. Box 1491, 90619-900 Porto Alegre, RS, Brazil. (ZMSL) lucenamargarete@gmail.com, Ohttps://orcid.org/0000-0003-4973-8340 (corresponding author); (CASL) lucena@pucrs.br, Dhttps://orcid.org/0000-0003-0546-5053 
Holotype. MZUSP 123642, 27.4 mm SL, unsexed; Brazil, Bahia, Campo Formoso, rio Salitre, on the road to Lage, ca. $40 \mathrm{~km}$ east of Lage, Poços de Doce, rio São Francisco drainage, approx. $10^{\circ} 01^{\prime} \mathrm{S} 40^{\circ} 42^{\prime} \mathrm{W}, 4$ Jan 1997, F. C. T. Lima \& P. Gerhard.

Paratypes. MCP 53629, 5 (2 c\&s), 18.2-27.5 mm SL (2, 25.5 and $26.7 \mathrm{~mm} \mathrm{SL})$, and MZUSP 51375, 63, 13.0-29.5 mm SL (8, 24.7-29.5 mm SL), same data as holotype.

Diagnosis. The presence of a conspicuously deep caudal peduncle spot, which reaches the upper and lower margins of the caudal peduncle, with a short extension onto the middle caudal fin rays and another weaker extension over the lower lobe of the caudal fin (Figs. 1-2) helps clearly distinguish Phenacogaster julliae from all its congeners, which lack the caudal peduncle spot or the extension over the lower lobe of caudal fin. Two species of the genus inhabit areas near the distribution of Phenacogaster julliae: P. franciscoensis, sympatric in the rio São Francisco basin, and Phenacogaster calverti Fowler of the coastal rivers of northeastern Brazil, immediately to the north of the rio São Francisco. In addition to the clearly differentiating feature mentioned earlier, $P$. julliae differs from $P$. franciscoensis in having a humeral spot in contact with, or slightly anterior to, the posterior margin of the pseudotympanum, corresponding to the posterior limit of the second rib, or immediately anterior to it (= to the first rib in Lucena, Malabarba, 2010) (vs. humeral spot distant from posterior margin of pseudotympanum by at least one scale, situated from the third rib, or immediately in front of the third rib); $P$. julliae differs from $P$. calverti in having a small third infraorbital, distant from the horizontal and vertical margins the preoperculum ( $v s$. a large third infraorbital, with posterior margin reaching the vertical margin of preoperculum and lower margin separated from the horizontal margin of preoperculum by a small space); two or three teeth in the medial region of the external premaxillary row (vs. one, rarely two); and the gently curved snout (vs. usually abrupt snout).

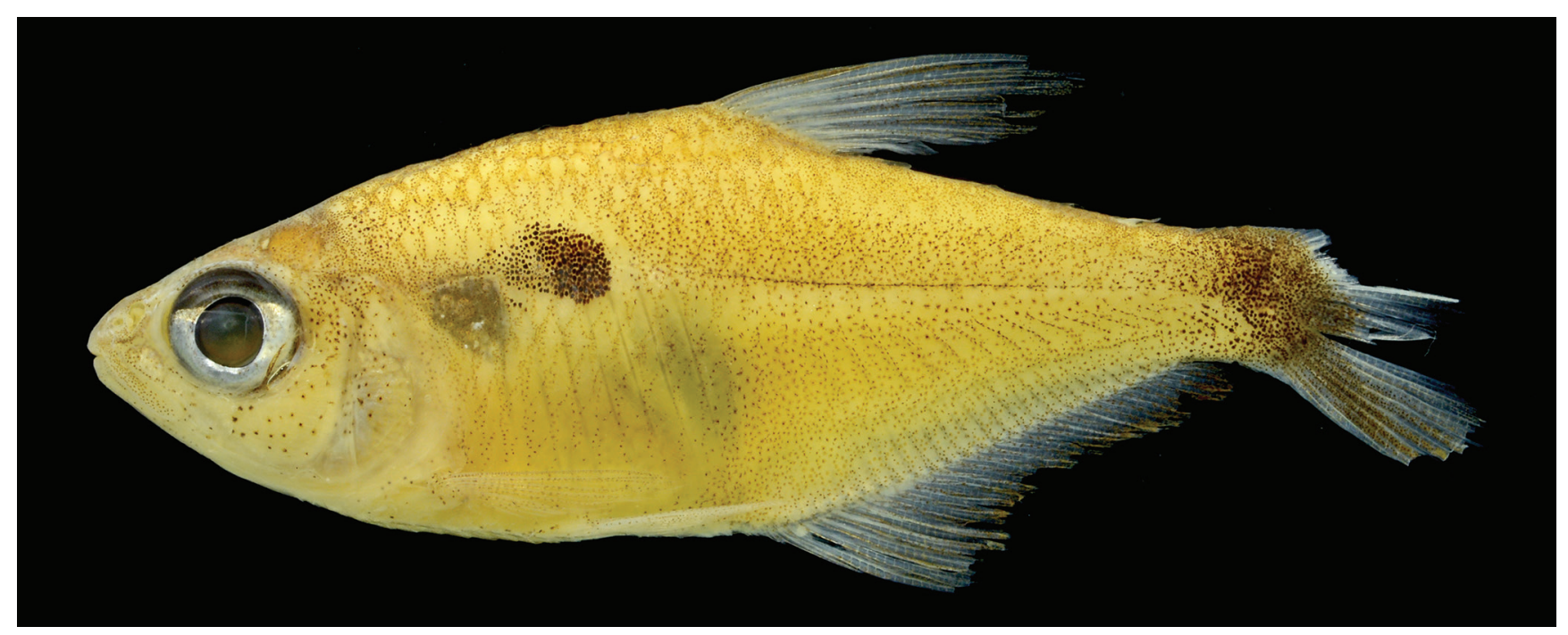

Fig. 1. Phenacogaster julliae, MZUSP 123642, holotype, unsexed, $27.4 \mathrm{~mm}$ SL, rio Salitre, Bahia state, Brazil.

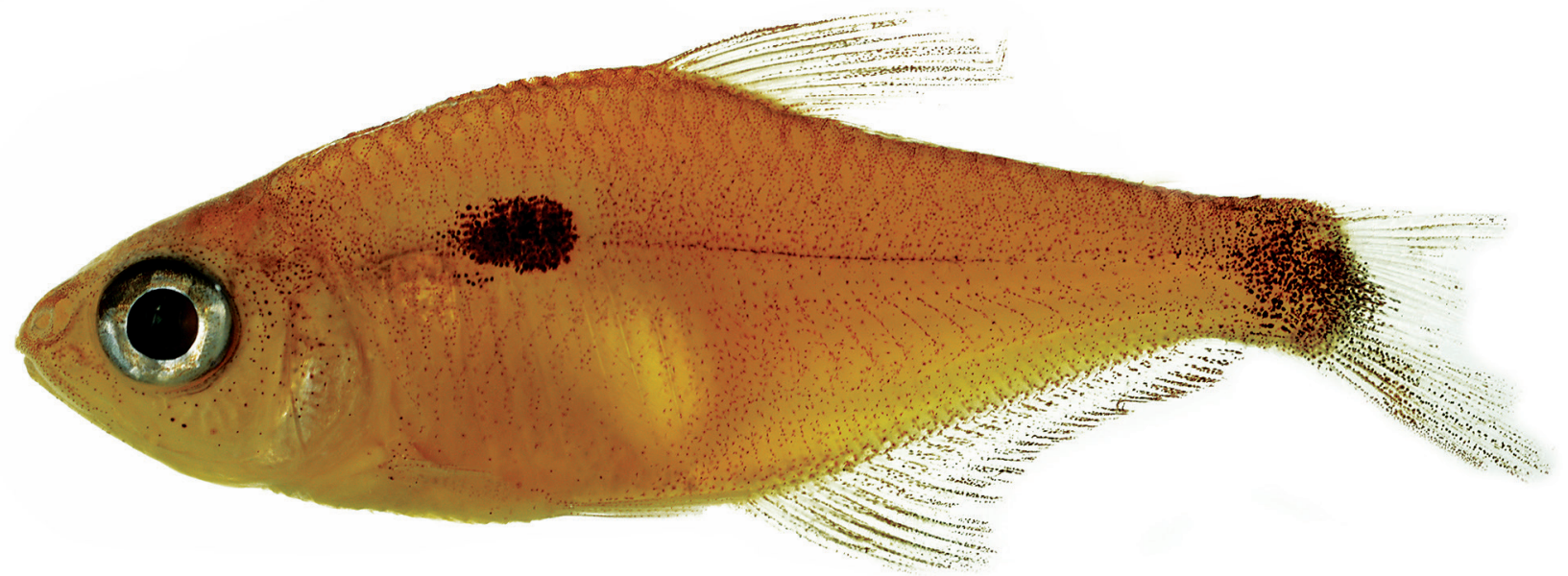

Fig. 2. Phenacogaster julliae, MZUSP 51375, paratype, male, $26.3 \mathrm{~mm}$ SL, rio Salitre, Bahia state, Brazil. 
Description. Morphometric data presented in Tab. 1. Body compressed. Dorsal profile of head convex from anterior tip of upper jaw to vertical through anterior border of orbit; straight to end of supraoccipital, or slightly convex in interorbital region, and convex to origin of dorsal fin. Dorsal profile between dorsal fin origin and origin of dorsal procurrent caudal-fin rays straight or slightly concave in peduncle. Ventral profile slightly convex from tip of mandible to anal-fin origin, or straight between pelvic-fin insertion and anal-fin origin. Body profile along anal-fin base straight or slightly convex. Ventral profile of caudal peduncle straight to slightly concave. Preventral area flattened.

Mouth slightly subterminal; posterior tip of maxilla reaches midway or immediately posterior to midway along infraorbital 2. Third infraorbital small, ventral and posterior margins of third infraorbital separated from preopercle by a broad space, and ventral margin separated by a larger space. Pseudotympanum extends from region immediately ahead of first rib to posterior border of second rib.

Two rows of teeth in premaxilla. External row with 6(2), $7(2)$, or $8^{*}(5)$ total teeth, complete or divided in medial sections by gap; medial section with 2(5) or 3(1) tricuspid teeth; lateral section with 4(3), 5(1), or 6(2) typically conical teeth. Three specimens with external row complete with $8^{*}$ teeth, and one cleared and stained with 9 teeth (two first teeth wide and tricuspid, followed by seven narrow and conical teeth). Internal row with $8 *(2), 9(3), 10(1), 11(1)$, or 12(1) teeth, first five teeth wide and tricuspid, followed by four narrow, tricuspid, conical teeth (in one cleared and stained specimen). Some specimens have one conical tooth lodged between internal and external rows on posterior portion of premaxilla. Maxilla with 26(1), 27(3), 30(1), 31(1), 32(1), or 35(1) conical teeth distributed along almost its entire length. Dentary with 16 or 18 teeth, in single row, with 6 tricuspid teeth followed by 1 bicuspid and 11 conical teeth, or by 10 conical teeth (Fig. 3).

Tab. 1. Morphometric data of holotype and paratypes of Phenacogaster julliae $(\mathrm{n}=$ number of specimens, holotype included). $\mathrm{SD}=$ standard deviation.

\begin{tabular}{|c|c|c|c|c|c|c|}
\hline & Holotype & $\mathrm{n}$ & \multicolumn{2}{|c|}{ Range } & Mean & SD \\
\hline Standard length (mm) & 27.4 & 10 & 24.7 & 29.5 & 27.2 & - \\
\hline \multicolumn{7}{|c|}{ Percents of standard length } \\
\hline Depth at dorsal-fin origin & 33.9 & 10 & 30.9 & 35.9 & 33.5 & 1.50 \\
\hline Predorsal distance & 54.0 & 10 & 49.2 & 54.0 & 51.4 & 1.58 \\
\hline Prepelvic distance & 40.9 & 9 & 36.6 & 40.9 & 38.8 & 1.29 \\
\hline Preanal distance & 55.5 & 10 & 51.7 & 58.6 & 53.9 & 1.96 \\
\hline Caudal-peduncle length & 7.3 & 10 & 7.3 & 10.3 & 8.8 & 0.90 \\
\hline Caudal-peduncle depth & 10.9 & 10 & 8.6 & 10.9 & 9.9 & 0.76 \\
\hline Head length & 28.8 & 10 & 25.3 & 28.8 & 27.0 & 1.02 \\
\hline \multicolumn{7}{|c|}{ Percents of head length } \\
\hline Snout length & 24.0 & 10 & 22.1 & 28.4 & 24.5 & 1.96 \\
\hline Orbital diameter & 41.7 & 10 & 39.7 & 47.1 & 43.1 & 2.37 \\
\hline Interorbital width & 26.7 & 10 & 24.1 & 30.7 & 27.1 & 2.02 \\
\hline
\end{tabular}

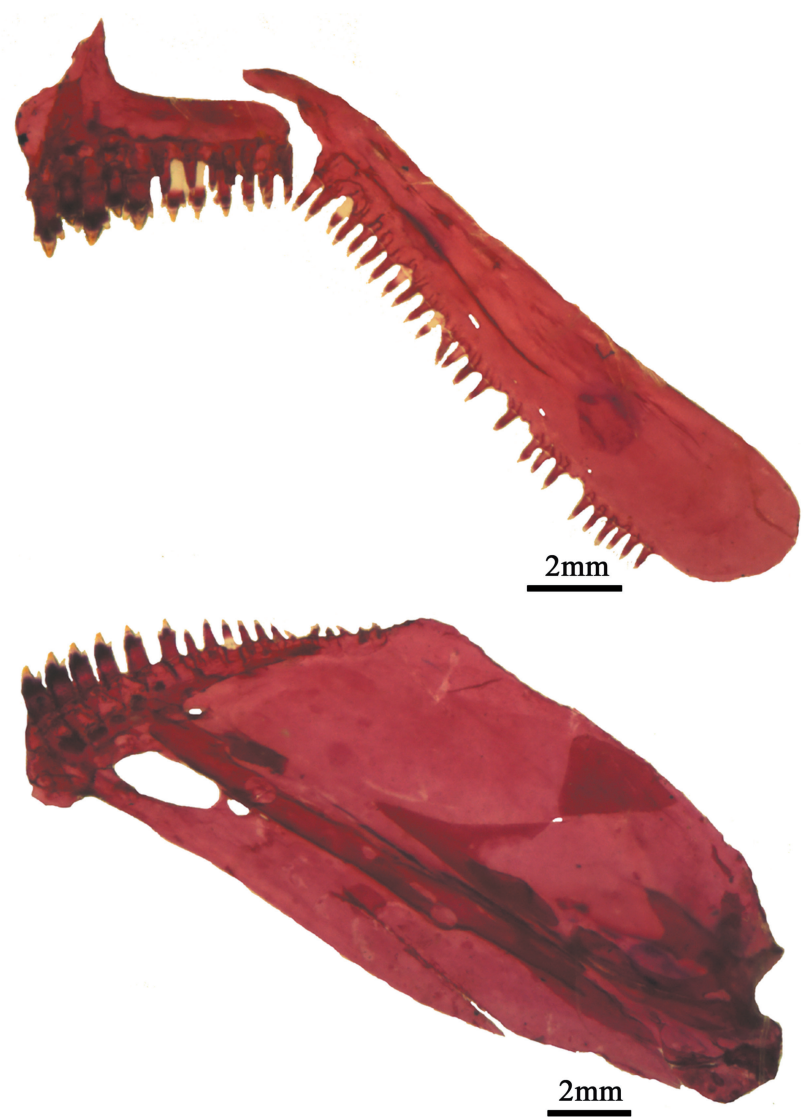

Fig. 3. Phenacogaster julliae, MCP 53629, $24.7 \mathrm{~mm}$ SL, paratype: maxilla (top right), premaxilla (top left), and lower jaw (bottom). Lateral view, left side.

Dorsal-fin rays ii, $7 *(3), 8(3)$, or $9(9)$. Anal-fin rays iii*, (9) or iv(1), 25(1), 26*(6), 27(5), 28(2), 29(6), its origin at vertical drawn between base of third or fourth branched ray of dorsal fin. Pectoral fin with i, 10*(6), 11(6), or 12(2) rays. Posterior tip of longest ray reaches approximately middle of pelvic-fin length in females and surpasses middle of pelvic-fin length in males. Pectoral-fin rays fully developed in specimens from SL of $16.0 \mathrm{~mm}$; and not developed or partially developed in smaller specimens. Posteroventral portion of cleithrum with gentle notch. Pelvic-fin rays i,7* (one specimen with $i, 6$ ), tip of fin reaching last unbranched anal-fin ray or first or second branched anal-fin ray.

Longitudinal scales $34(3), 35(3), 36^{*}(8)$, or 37(1) usually interrupted with 9 to 17 perforated scales followed by non-perforated and perforated scales, last 3 or 4 scales are non-perforated; two specimens with complete lateral line (34 and 36 perforated scales) and one with incomplete lateral line (32 perforated scales followed by 3 non-perforated scales). Scale rows between dorsal fin and lateral line 6 (one specimen with 7). Scale rows between lateral line and anal-fin origin $4 *(20)$ or $5(3)$.

Gill rakers on upper limb of first gill arch 3(4), 4(12), or $5 *(6)$; gill rakers on lower limb $7(1), 8(14)$ or $9 *(7)$.

Total vertebrae 33(2): precaudal 14(1) or 15(1), caudal 18(1) or 19(1). Supraneurals 4(2). 
Color in alcohol. General coloration of the body is yellowish. Laterodorsal region with brown chromatophores on the edge of scales near back and more scattered below. Lateroventral region, between origins of pectoral fins until region in the front of anal fin, is less pigmented. Chromatophores are spread and/or arranged in the form of " $>$ " throughout the region between lateral line and anal fin, demarcating myosepta. Dorsal region of head and back of the body pigmented; pigments are principally present on the border of scales in the anterior region of smaller individuals (around $20 \mathrm{~mm}$ SL). Humeral spot large, conspicuous, ovate, with a pale area around it, positioned above 5th or 6th to 9th scale of lateral line, extending from the end of pseudotympanum, or immediately before, to right after 6th or 7th rib. Center of humeral spot slightly below or at horizontal line through the dorsal border of pseudotympanum.

Dark midlateral line on the body from immediately after humeral spot until the origin of caudal peduncle spot. Band of chromatophores are present throughout and above midlateral line, and below is a pale hypopigmented band. Conspicuous, deep caudal peduncle spot reaches upper and lower margins of the caudal peduncle, extending on middle caudal-fin rays and more weakly on the lower lobe of caudal fin (Figs. 1-2). Anal fin with scarcer pigments, less intense in the medial region of the fin starting from 6th or 7th branched ray, leaving a pale area between the margin and the base; holotype relatively more pigmented in this area. Pectoral fin with pigments along ray margins. Pelvic fin with pigments along the rays, extremely pale, last ray pale or has significantly little pigment. Adipose fin is pale.

Sexual dimorphism. Eight specimens of 21.1-26.3 mm SL exhibit retrorse bony hooks on anal- and pelvic-fin rays. Hooks on last unbranched to 7th or 11th branched anal-fin rays. One, rarely two, hooks per segment of lepidotrichia. First unbranched ray to last or penultimate branched ray of pelvic fin bearing retrorse bony hooks located along medial border of second branch and on the principal branch. One hook per segment of lepidotrichia.

Geographical distribution. Known only from the type locality (Fig. 4).

Etymology. The species name is julliae, named in honour of our granddaughter Jullia, who was born during the description of this species.

Conservation status. Phenacogaster julliae is described based on 69 specimens collected in January 1997 from the middle rio Salitre basin, about $40 \mathrm{~km}$ from Lage, Bahia. The rio Salitre basin is considered intermittent and is located in the lower middle rio São Francisco in an area with low rainfall index, irregular rains, and water deficit because of elevated evaporation rates (Oliveira et al., 2010). In an email from Flávio Lima in July 2018, we were informed that the species was found in a narrow stretch of the river with a noticeable aquatic vegetation, transparent water, and slow flow, alternating between shallow areas with rapid flow and other slower, deeper areas reaching a depth of about $2 \mathrm{~m}$. We do not have information on current conditions of the locality; however, the rio Salitre basin, which has a history of conflict over water use, faces various threats: incompatible irrigation methods, development of soil cultivation on the banks of the rivers and lakes of dams, superficial water with a high level of salinity and pollution caused by anthropic activity (untreated sewage, among others) (FEP, 2003). Furthermore, there are transposition projects, specifially the Sertão Baiano or Eixo-Sul Canal [transposition of the rio São Francisco] that runs from the rio São Francisco, starting from the Sobradinho Reservoir to the rio Itapicuru and Jacuípe water basins, influencing some basins along this path, including the Salitre (Nemus, 2015). Considering these threats faced by the rio Salitre basin and the apparent rarity of the species, Phenacogaster julliae can be categorized as Data Deficient according to the IUCN criteria (IUCN, 2017).

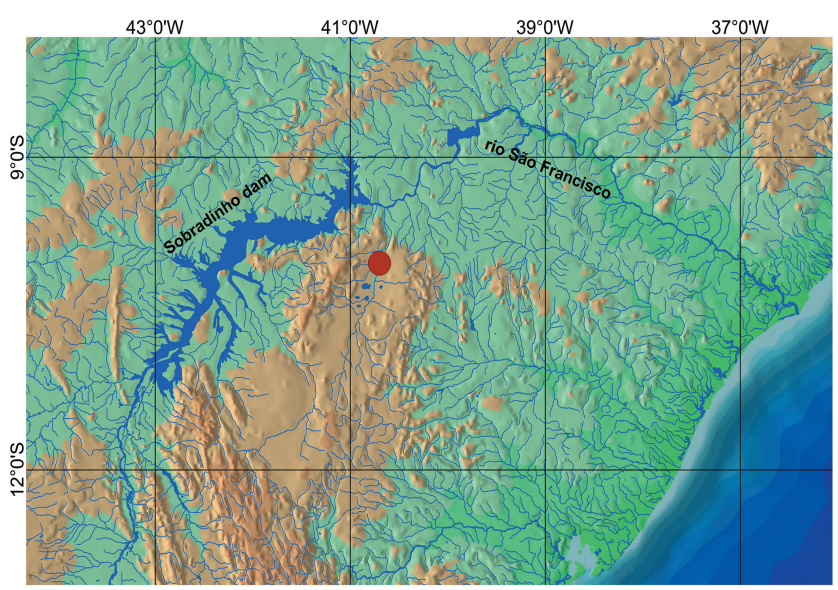

Fig. 4. Known distribution of Phenacogaster julliae. Red dot represents the type locality.

\section{Discussion}

Phenacogaster julliae seems not to exceed $29.5 \mathrm{~mm}$ $\mathrm{SL}$, the smallest size recorded among the species of the genus which can reach from $36 \mathrm{~mm} \mathrm{SL}$ (P. carteri) to 61 $\mathrm{mm}$ SL ( $P$. megalostictus Eigenmann). Male examined specimens of $21.1 \mathrm{~mm} \mathrm{SL}$ or larger exhibit hooks on their fins, indicating that they reach sexual maturity at this size. The association between hooks and sexual maturity is recorded for various taxa in Characiformes (Lampert et al., 2004; Gonçalves et al., 2005).

Phenacogaster julliae has a pectoral fin in the larval form only in individuals less than $16 \mathrm{~mm} \mathrm{SL}$, differing from most of species of the genus, in which larval pectoral fin is present in individuals up to $20 \mathrm{~mm} \mathrm{SL}$, or even in individuals larger than 25 or $30 \mathrm{~mm}$ SL. Only P. franciscoensis, P. retropinna Lucena \& Malabarba, and P. tegata Eigenmann $(17.5,17.9$, and $18.2 \mathrm{~mm} \mathrm{SL}$, respectively) have presented a totally developed fin in individuals less than 20 
$\mathrm{mm}$ SL. Although retention of the larval form of pectoral fin in P. julliae occurs in individuals less than $16 \mathrm{~mm} \mathrm{SL}$, distinct from other species of the genus, it still supports the proposal of the permanence of the larval fin in specimens of relatively large size as a potential synapomorphy for a clade composed of Acanthocharax Eigenmann, Acestrocephalus Eigenmann, Charax Scopoli, Cynopotamus Valenciennes, Galeocharax Fowler, Phenacogaster, and Roeboides Günther in accordance with that suggested by Lucena (1998). According to Weitzman, Vari (1987), many Characidae convert from the larval form of pectoral fin to an adult form when they reach 6 to $9 \mathrm{~mm}$ SL.

The rio São Francisco drainage is well sampled in its lower course (Luz et al., 2009, 2012; Stegmann, 2012); however, the rio Salitre, perhaps because of its intermittent characteristics, has been little explored in terms of its ichthyofauna. The oldest records for the drainage are from collections of Haseman in 1907 (Haseman, Eigenmann, 1911), specimens of which were deposited in the Field Museum of Natural History and represent the following species: Astyanax bimaculatus (Linnaeus), A. fasciatus (Cuvier), Cichlasoma bimaculatum Linnaeus (probably $C$. sanctifranciscense Kullander), Creatochanes sp., Crenicichla lepidota Heckel, Hoplias malabaricus (Bloch), Leporinus taeniatus Lütken, and Megalamphodus (= Hyphessobrycon) micropterus (Eigenmann). Ninety years later, Flávio Lima undertook a field trip to the rio Salitre and collected specimens of 10 species, including Phenacogaster julliae; those specimens were deposited in the Museu de Zoologia da Universidade de São Paulo and represent the following species: Characidium bahiense Almeida, Characidium sp., Cichlasoma aff. facetum (= Australoheros aff. facetus (Jenyns)), C. sanctifranciscense Kullander, Hyphessobrycon cf. callistus Boulenger (= Hyphessobrycon eques (Steindachner)), Hyphessobrycon sp., Hoplias sp., Odontostilbe cf. piaba (= Serrapinnus piaba (Lütken)), and Pamphorichthys hollandi (Henn). The literature indicates the occurrence of a total of 15 species in the rio Salitre basin (Stegmann, 2012), six recorded in Stegmann et al. (2007) and nine in FADURPE(2008), and among them are Leporinus piau Fowler, Astyanax fasciatus, A. bimaculatus, Hemigrammus brevis Ellis, Moenkhausia costae (Steindachner), Poecilia sp., Serrapinnus heterodon (Eigenmann), and $S$. piaba. These surveys, however, did not capture specimens of Phenacogaster, though P. franciscoensis occurs in the stretch of the rio São Francisco downstream from the Sobradinho dam, in the mouth of the rio Salitre (Luz et al., 2009, 2012). The apparent non-sympatry of $P$. julliae and P. fransciscoensis in the rio Salitre may be related to the lack of sampling in this sub-basin.

Comparative material. As listed by Lucena, Malabarba (2010) and Antonetti et al. (2018). Additional examined specimens are as follows (all from Brazil): Phenacogaster fransciscoensis: Brazil, rio Tocantins-Araguaia drainage, MNRJ 25248, 1, $33.3 \mathrm{~mm} \mathrm{SL}$ and MZUSP 89365, 8, 7.7-50.7 mm SL.

\section{Acknowledgments}

ZMSL thanks Flávio Lima from the Museu de Zoologia da Universidade de Campinas for bringing the specimens of the new species to her attention. We acknowledge Paulo Buckup (MNRJ), José Lima Figueiredo and Osvaldo Oyakawa (MZUSP) for loaning specimens under their care. Barbara Calegari (MCP) prepared Figs. 1 and 2.

\section{References}

Antonetti DA, Lucena CAS, Lucena ZMS. Two new species of Phenacogaster (Actinopterygii: Characidae) from the rio Tocantins drainage, Brazil. Ichthyol Explor Freshw [serial on the Internet]. 2018; 28(3):271-80. Available from: https://doi. org/10.23788/IEF-1075

Casciotta R, Almirón AE, Sanchez S, Bechara JA. Phenacogaster tegatus (Eigenmann, 1911), un nuevo integrante de la ictiofauna continental Argentina. Rev Ictiol. 2003; 9(1/2):1-3.

Eigenmann $\mathrm{CH}$. New characins in the collection of the Carnegie Museum. Ann Carnegie Mus. 1911; 8(1):164-81.

Fink WL, Weitzman SH. The so-called Cheirodontin fishes of Central America with descriptions of two new species (Pisces: Characidae). Washington (DC): Smithsonian Institution Press; 1974 (Smithsonian Contributions to Zoology no. 172).

Fundação Apolônio Salles (FADURPE). Programa de inventário dos ecossistemas aquáticos do reservatório de Sobradinho. $1^{\circ}$. Relatório Anual das Atividades Outubro/2006 a Setembro/2007 [Internet]. 2008. Available from: http:// licenciamento.ibama.gov.br/Hidreletricas/Sobradinho/ Relatorios/IN VEN T \% C 3\%8 1 RIO \% 20 D O S \% 20 ECOSSISTEMAS\%20AQU\%C3\%81TICOS\%20DO \%20 RESERVAT\%C3\%93RIO\%20DE\%20SOBRADINHO $\% 20$ -\%201\%C2\%B0\%20relat\%C3\%B3rio\%20anual.pdf

Fundação Educacional Politécnica (FEP). Plano de gerenciamento integrado da bacia do rio Salitre. Resumo Executivo do Relatório Anual [Internet]. 2003. Available from: https://pt.scribd.com/ document/274098454/Plano-de-Gerenciamento-Integrado-daBacia-do-Rio-Salitre-pdf

Gonçalves TK, Azevedo MA, Malabarba LR, Fialho CB. Reproductive biology and developement of sexually dimorphic structures in Aphyocharax anisitsi (Ostariophysi: Characidae). Neotrop Ichthyol [serial on the Internet]. 2005; 3(3):433-38. Available from: http://dx.doi.org/10.1590/S167962252005000300012

Haseman JD, Eigenmann CH. A brief report upon the expedition of the Carnegie Museum to Central South America together with a list of localities at which Mr. Haseman collected. Ann Carnegie Mus. 1911; 7(3-4):287-314.

International Union for Conservation of Nature (IUCN). Standards and Petitions Subcommittee. Guidelines for using the IUCN red list categories and criteria. Version 13 [Internet]. 2017 [updated 2017 Mar]. Available from: http://cmsdocs.s3.amazonaws. com/RedListGuidelines.pdf

Lampert VR, Azevedo MA, Fialho CB. Reproductive biology of Bryconamericus iheringii (Ostariophysi: Characidae) from rio 
Vacacaí, RS, Brazil. Neotrop Ichthyol [serial on the Internet]. 2004; 2(4):209-15. Available from: http://dx.doi.org/10.1590/ S1679-62252004000400003

Lucena CAS. Relações filogenéticas e definição do gênero Roeboides, Günther (Ostariophysi; Characiformes; Characidae). Comun Mus Ciênc Tecnol PUCRS . 1998; 11:1959. (Série Zoologia).

Lucena ZMS, Malabarba LR. Descrição de nove espécies novas de Phenacogaster (Ostariophysi: Characiformes: Characidae) e comentários sobre as demais espécies do gênero. Zoologia. 2010; 27(2):263-304.

Luz SCS, El-Deir ACA, França EJ, Severi W. Estrutura da assembléia de peixes de uma lagoa marginal desconectada do rio, no submédio Rio São Francisco, Pernambuco. Biota Neotrop [serial on the Internet]. 2009; 9(3):117-29. Available from: http:/www.biotaneotropica.org.br/v9n3/en/ abstract?article+bn01809032009

Luz SCS, Lima HC, Severi W. Composição da ictiofauna em ambientes marginais e tributários do médio-submédio rio São Francisco. Rev Bras Ciênc Agr [serial on the Internet]. 2012; 7(2):358-66. Available from: https://www.redalyc.org/ comocitar.oa? $\mathrm{id}=119023684024$

Malabarba LR, Lucena ZMS. Phenacogaster jancupa, new species, with comments on the relationships and a new diagnosis of the genus (Ostariophysi: Characidae). Ichthyol Explor Freshw. 1995; 6(4):337-44.

Nemus, Gestão e Qualificação Ambiental. Plano de Recursos hídricos da bacia hidrográfica do rio São Francisco. Diagnóstico consolidado da bacia hidrográfica do rio São Francisco. Volume 1 [Internet]. Lisboa: Nemus, Gestão e Qualificação Ambiental Ltda; 2015. Available from: http://cbhsaofrancisco. org.br/planoderecursoshidricos/wp-content/uploads/2015/04/ RP2_V1_Diagnostico_Consolidado.pdf
Oliveira CN, Campos VP, Medeiros YDP. Avaliação e identificação de parâmetros importantes para a qualidade de corpos d'água no semiárido baiano. Estudo de Caso: bacia hidrográfica do rio Salitre. Quim Nova [serial on the Internet]. 2010; 33(5):105966. Available from: http://www.repositorio.ufba.br/ri/handle/ ri/3785

Stegmann LF. Estrutura da ictiofauna ao longo do eixo longitudinal em um trecho segmentado do submédio rio São Francisco. [MSc Dissertation on the Internet]. Recife: Universidade Federal de Pernambuco; 2012. Available from: Repositório Institucional da UFPE. qhttps://repositorio.ufpe.br/handle/123456789/10178

Stegmann LF, Silva KMS, Luz SCS, França EJ, El-Deir A, Severi W. Composição ictiofaunística dos seis tributários submédio do rio São Francisco, Brasil. In: Anais do VIII Congresso de Ecologia do Brasil. Caxambú: Sociedade Brasileira de Ecologia; 2007. p1-2.

Taylor WR, Van Dyke GC. Revised procedures for staining and clearing small fishes and other vertebrates for bone and cartilage study. Cybium [serial on the Internet]. 1985; 9(2):10719. Available from: http://sfi-cybium.fr/en/node/ 2423

Weitzman SH, Vari RP. Two new species and a new genus of miniature characid fishes (Teleostei: Characiformes) from northern South America. Proc Biol Soc Wash. 1987; 100(3):640-52. 